\title{
Using Leaf Traits to Rank Native Grasses According to Their Nutritive Value
}

\author{
Raouda Al Haj Khaled, ${ }^{1}$ Michel Duru, ${ }^{2}$ Virginie Decruyenaere, ${ }^{3}$ \\ Claire Jouany, ${ }^{4}$ and Pablo Cruz ${ }^{5}$
}

\begin{abstract}
Authors are ${ }^{1}$ Post-graduate student, and ${ }^{2}$ Leader in Agronomy, UMR1428 ARCHE, INRA, BP 27, 31326 Castanet-Tolosan, France; ${ }^{3}$ Plant Scientist, Centre Wallon de Recherches Agronomiques, Section Systèmes agricoles, 100 rue du Serpont, B-6800 Libramont, Belgium; ${ }^{4}$ Soil Scientist, and ${ }^{5}$ Plant Scientist, UMR1428 ARCHE, INRA, BP 27, 31326 Castanet-Tolosan, France.
\end{abstract}

\begin{abstract}
Leaf traits (leaf dry matter content [LDMC], specific leaf area [SLA] and leaf life span [LLS]) previously proposed to predict plant strategies for resource use, were studied to test if they can be used to rank grasses for digestible organic matter (DOM). On 14 native grass species from natural meadows in the French Pyrenees, leaf blade chemical components (fiber, cellulose, hemicellulose and lignin) and DOM were estimated for two growing periods using two different methods (chemical-enzymatic and Near Infrared Reflectance Spectroscopy). The ranking of species based on LDMC, SLA and LLS was conserved. Fiber content and DOM were significantly correlated even though the data were obtained in different years (2001 and 2002), on different organs (youngest adult blades in 2001 and all the green blades of tillers in 2002) and by different analytical methods. LDMC seems to be the most suitable trait to rank native grasses according to their nutritive value because it ranks species as well as leaf traits and it is the easiest to measure. We suggest using LDMC as an indicator to rank grassland communities for herbage nutritive values.
\end{abstract}

\section{Resumen}

Tres atributos foliares, el contenido en materia seca (LDMC), el área foliar específica (SLA) y la longevidad foliar (LLS) fueron estudiados sobre 14 gramíneas nativas de praderas situadas en los Pirineos franceses para determinar si dichos atributos las clasifican en el mismo orden que variables de valor nutritivo. Para esto, la composición química (fibra, celulosa, hemi-celulosa y lignina) y la digestibilidad de la materia seca (DOM) de las laminas foliares fueron estimados durante dos períodos de crecimiento utilizando métodos diferentes (químico-enzimático y espectroscopia o NIRS). LDMC, LLS y SLA clasifican las especies de igual manera en que lo hacen la proporción de fibras y la DOM. La composición de tejidos foliares y la DOM mostraron une correlación significativa aún cuando los datos fueron obtenidos con métodos analíticos diferentes, en años diferentes y sobre muestras de órganos diferentes (la lámina de la hoja adulta mas joven en 2001 y todas las láminas verdes en 2002). La LDMC se presenta como el mejor atributo para clasificar las especies por su valor nutritivo pues las ordena como los otros y su medición es más simple. Este atributo puede ser usado para clasificar comunidades herbáceas naturales según su valor nutritivo.

Key Words: tissue composition, digestibility, leaf dry matter content, leaf life span, specific leaf area

\section{INTRODUCTION}

The management of native grasslands-herbaceous vegetation with a very diverse flora and a wide range of uses-should meet environmental conservation concerns and improve the quality of forage production (Duru et al. 2005). The management of grasslands needs tools for diagnosing the state of the vegetation, especially their nutritive value, in order to design, evaluate, and apply management practices to attain these aims.

The main chemical composition criteria that determine nutritive value for herbivores are the concentration of neutral-detergent fiber, acid-detergent lignin, nitrogenous compounds, minerals, and plant-digestible organic matter (Hopkins et al. 2002). Research on forage nutritive value other than in vivo assessment can be roughly divided into 3

Correspondence: Raouda Al Haj Khaled, UMR1428 ARCHE, INRA, BP 27, 31326 Castanet-Tolosan, France. Email: ralhajk@yahoo.com

Manuscript received 14 February 2005; manuscript accepted 16 July 2006. approaches. The first approach aims to predict nutritive value using a set of enzymatic or physical methods (Van der Honing and Alderman 1988). For this approach, major studies have been carried out to calibrate models and to determine a simple and accurate method to predict the nutritive value for various kinds of forage, i.e., different species, different botanical families (Poaceae, Fabaceae) or different forage stands (improved and native species). At the farm level, this approach is often not feasible because it is time-consuming and expensive. A second approach aims to roughly assess forage quality based on the phenological stages of species present in a grassland community (Demarquilly and Jarrige 1981; Fick et al. 1994) possibly supplemented by observations on the morphological composition (Demarquilly 1989), leading to published tables of nutritive values of forage species. This approach is mainly used for short-term predictions of nutritive value of pure stands composed of improved grasses or legumes (Fick et al. 1994). Such an approach is not easy to apply for predicting the nutritive value of species-rich natural grasslands either within or between communities (Bruinenberg et al. 2002). Natural 
meadows and grasslands vary in their botanical composition and their herbage mineral status (Duru 1994). For these complex types of vegetation, a third approach, based on botanical records, has been proposed (De Vries 1937; Delpech 1960; Klapp 1965; Daget and Poissonnet 1971; Balent and Duru 1984; Dorioz and Party 1987). This approach aims to rank grassland communities for their nutritive value, and not to predict it for a given time of the year. For example, Daget and Poissonnet (1971) proposed to compute at plant community level an index (pastoral value) based on individual species indices weighted by their relative abundance. These indices were empirically established on a scale from 0 to 5 , but have not been validated using plant tissue chemical or enzymatic analysis as proposed by Tilley and Terry (1963). Moreover, plant analyses have rarely been done on native grassland species, particularly those growing in nutrient-poor habitats.

In this paper, we intend to propose an alternative approach to ranking grass species according to their digestible organic matter (DOM) which needs to be evaluated in further work at the plant community level. Our study was based on the Plant Functional Type (PFT) approach, developed in previous plant ecology studies. The basis of PFT rests on an analysis of the functional traits of the species. We focus on "effect traits" which act on the processes of the ecosystem and determine its properties (herbage quality in our case) (Diaz et al. 1999; Lavorel and Garnier 2002). Leaf traits like specific leaf area (SLA: the ratio of saturated leaf area to leaf dry mass), leaf dry matter content (LDMC: the ratio of leaf dry mass to saturated fresh mass) and leaf life span (LLS: time elapsed from leaf appearance, tip of the lamina visible outside the sheath, until the start of senescence) are proposed to fulfill this aim. Furthermore, previous research has shown that these traits rank species in a consistent manner whatever the nitrogen availability level and in different growing seasons (Al Haj Khaled et al. 2005). Some studies have revealed a relationship between cell wall material and leaf traits, and between leaf tissue composition and digestibility (Scehovic 1979; Daccord 1991; Daccord et al. 2001), but there are no studies relating leaf traits to DOM. Species having a low relative growth rate (RGR: the increase in biomass per unit of biomass per unit time) are in a greater abundance in nutrient-poor habitats (Lambers and Poorter 1992; Meziane and Shipley 1999). These species are characterized by a lower SLA, longer LLS (Reich et al. 1992; Ryser and Urbas 2000), and higher leaf tissue density (Reich et al. 1992; Ryser 1996), and contain proportionally more cell wall material (cellulose, hemicelluloses and lignin). Moreover, leaves having long LLS show a high fiber/crude protein ratio, high lignin concentration and low nitrogen and phosphorus concentration (Eckstein et al. 1999). Conversely, species from nutrient-rich habitats show opposite leaf trait values. They contain proportionally more cytoplasm elements (Niemann et al. 1992), have a low proportion of cell wall per unit leaf area, a high proportion of mesophyll protoplast per unit volume and high organic nitrogen concentration (Poorter et al. 1990; Garnier and Laurent 1994). Different proportions of leaf mesophyll (highly digestible tissue) among herbaceous species result in a wide range of nutritive values (Daccord 1991; Nelson and Moser 1994; Groot and Neuteboom 1997).

In this paper, we ask if these leaf traits (LDMC, SLA and LLS) that have been shown relevant for ranking species for their
Table 1. List of studied species and their index for nutritive value.

\begin{tabular}{lc}
\hline \multicolumn{1}{c}{ Species } & IS \\
\hline Agrostis capillaris L. & 3 \\
Anthoxanthum odoratum L. & 1 \\
Arrhenatherum elatius (L.) Beauv. & 4 \\
Avenula pubescens (Huds.) Dumort & 3 \\
Brachypodium pinnatum (L.) P. Beauv. & 1 \\
Brachypodium sylvaticum (Huds.) Beauv. & $\mathrm{ND}$ \\
Briza media L. & 1 \\
Dactylis glomerata L. & 5 \\
Festuca arundinacea L. & 3 \\
Festuca ovina L. & 1 \\
Festuca rubra L. & 2 \\
Holcus lanatus L. & 2 \\
Lolium perenne L. (cv) Clerpin & 5 \\
Lolium perenne L. & 5 \\
\hline
\end{tabular}

$I_{S}$ is the specific index proposed by Daget and Poissonnet (1971) where 1 and 5 indicate respectively low and high species nutritive value. $\mathrm{ND}=$ value not defined.

RGR (Lambers and Poorter, 1992), and for their phenological stages (Ansquer et al. 2004) are also able to rank them for DOM. Considering the relationship existing between cell wall material and leaf traits, and between leaf tissue composition and digestibility as described above, we hypothesized that there are significant correlations between leaf traits and leaf DOM.

\section{MATERIALS AND METHODS}

\section{Experimental Site}

The study was carried out close to Toulouse, France $\left(1^{\circ} 43^{\prime} \mathrm{E}\right.$, $\left.43^{\circ} 5^{\prime} \mathrm{N}\right)$. The altitude is $150 \mathrm{~m}$ above sea level; the mean annual precipitation is $700 \mathrm{~mm}$ and the mean daily temperature is $13^{\circ} \mathrm{C}$. The soil, a clayey loam, is a fluvisol developed on alluvial sediments, a tertiary deposit coming from the Pyrenees. Soil characteristics are: $\mathrm{pH}$ (water) 8.0, organic matter content 16 $\mathrm{mg} \cdot \mathrm{kg}^{-1}$ soil, available P concentration $50 \mathrm{mg} \cdot \mathrm{kg}^{-1}$ soil (Olsen et al. 1954) and total P concentration $0.65 \mathrm{~g} \cdot \mathrm{kg}^{-1}$ soil. Fourteen grasses (Table 1) were sown in pure stands on 27 October 2000 using a randomized block design with 3 replicates. The species were chosen according to their contribution to the biomass of native grasslands in the Pyrenean Mountains. The seeds of most of the species were collected in their native habitat on several paddocks of a valley in the Central Pyrenees $\left(1^{\circ} 17^{\prime} \mathrm{E}, 42^{\circ} 51^{\prime} \mathrm{N}\right.$, 600-900 m asl). Only Festuca ovina L. (a native population) and Lolium perenne L. (cv) Clerpin were provided by the INRA Poitou Charentes Research Centre. Clerpin ryegrass was included as a control common to several experiments in progress in different regions of France. Each basic plot consisted of 8 rows $1.2 \mathrm{~m}$ long, $15 \mathrm{~cm}$ apart. There was no limitation in nitrogen, phosphorus, potassium or water. The non-limiting growing conditions enabled us, because of their invariant and reproducible nature, to use them as a control for the comparison of factors having an effect on plant traits.

Nitrogen applications were $120 \mathrm{~kg} \cdot \mathrm{ha}^{-1}$ for the 2001 summer growth and $150 \mathrm{~kg} \cdot \mathrm{ha}^{-1}$ for the 2002 spring growth. The whole experimental area received $150 \mathrm{~kg}$ of $\mathrm{P}\left(\mathrm{CaH} \mathrm{PO}_{4}\right)$ and $\mathrm{K}$ $(\mathrm{KCl}) \cdot \mathrm{ha}^{-1} \cdot$ year $^{-1}$ and was irrigated with a sprinkler system in 
order to maintain soil moisture content close to field capacity. Weeds were controlled manually throughout the experiment.

\section{Leaf Sampling for Nutritive Value Analysis}

In order to analyze for chemical composition and the digestible organic matter (DOM), leaf blades were sampled on all replicates and species for both growth years. In 2001, the youngest fully-expanded blades of sampled tillers were harvested from 15 to 23 July (trial 1). In 2002, on 17 February, all the plots were cut at $5 \mathrm{~cm}$ height, then all the green blades of sampled tillers for a given species were harvested when its reproductive apex reached $10 \mathrm{~cm}$ height (trial 2 ). The harvest period lasted from 29 March until 17 June.

\section{Tissue Composition and Digestibility}

On the 2001 samples the Van Soest and Wine method (1967) was carried out to determine the chemical composition (fiber content, cellulose, hemi-cellulose, lignin), and an enzymatic method (Aufrère 1982) was used to estimate their digestible organic matter (IV-DOM). The enzymatic method involved hydrolysis with pepsin in acid conditions $(0.1 \mathrm{~N} \mathrm{HCl})$ for 24 hours at $40^{\circ} \mathrm{C}$, heating the solution to $80^{\circ} \mathrm{C}$ for 30 minutes at the end of the pepsin hydrolysis, followed by enzymatic hydrolysis with a fungal cellulase in sodium acetate buffer with $\mathrm{pH} 4.6$ for $24 \mathrm{~h}$ at $40^{\circ} \mathrm{C}$.

In 2002, leaf samples were submitted to near infrared reflectance spectroscopy (NIRS) analysis to estimate their chemical components and DOM (NIRS-DOM) (NIRS system monochromator 5000, Libramont, Belgium). Because of the small amount of sample available ( 0.5 to $1 \mathrm{~g}$ of powder), mini ring cups with quartz lenses used for NIRS analysis were reduced with micro-inserts of $18 \mathrm{~mm}$ diameter. All spectral data in the range of 1100-2500 $\mathrm{nm}$ by 2 -nm steps were recorded as $\log (1 /$ Reflectance $[\mathrm{R}])$. Using NIRS analysis to predict the main characteristics of organic compounds requires adequate calibration. This is done using a mathematical model that relates chemical information contained in the electromagnetic spectrum to chemical information obtained by reference laboratory methods. Thus, when calibrations exist it is easy to estimate the component of interest using only NIRS. NIRS calibrations used in this study were constructed using the Partial Least Square method (Marten and Jensen 1982) with cross validation on the first derivative of the absorption spectra (reflection mode) between 1300 and $2400 \mathrm{~nm}$. Cross validation is used to validate the calibration. With this procedure each sample in the calibration is predicted. Usually, 4 cross validations are performed to build the calibration (WINISI II 1998). For DOM, the calibration used was developed from the Aufrère (1982) reference laboratory. This calibration consists of a large database $(\mathrm{N}=$ 1616; average DOM $=708.4-\mathrm{g} \cdot \mathrm{kg}^{-1}$; standard error of calibration $=23.7-\mathrm{g} \cdot \mathrm{kg}^{-1}$, standard error of cross validation = 24.2-g $\left.\cdot \mathrm{kg}^{-1}, r^{2}=0.95\right)$ containing perennial grasslands and grass-legume mixtures collected in Belgium, France, Luxembourg, Tunisia, and the Netherlands (Biston and Dardenne 1985; Dardenne and Biston 1991; Dardenne et al. 1996).

\section{Plant Measurements for Leaf Traits}

LDMC and SLA were measured during 2 growing years corresponding to summer 2001 (from 28 May to 13 June) and spring 2002 (from 30 March to 27 May). The protocol of measurements was extensively explained by $\mathrm{Al}$ Haj Khaled et al. (2005).

LLS (expressed in degree-days; $0^{\circ} \mathrm{C}$ base temperature) was determined from the beginning of each growth cycle. On 6 May 2001, 5 leaves (reaching their final size: time when the ligule became visible) per species and per replication were ringed and monitored until their start of senescence, which corresponds to the adult life span of leaves. On 26 March 2002, 5 leaves per species and per replication were ringed and then monitored 3 times a week in order to record the date when the following leaf appeared. This new leaf was monitored through to its senescence, which corresponds to the life span of the leaf from its appearance. LLS is expressed in degree-days $\left(0^{\circ} \mathrm{C}\right.$ base temperature).

\section{Data Analysis}

Spearman rank coefficients (Sheskin 2004) were calculated to test whether the species rankings for SLA, LDMC and LLS, measured for each growing year, and for their average values across growth periods, were similar to those for fiber content, its components and DOM measured in the two trials. The same test was used to examine whether the species ranking performed by nutritive value criteria was conserved between the 2 trials, as well as between these criteria and Daget and Poissonnet indices (1971). Leaf traits recorded in the two years were averaged because we have previously shown that there was no significant difference for their ranking between growing seasons (Al Haj Khaled et al. 2005).

Finally, a hierarchical cluster analysis (Everitt 2001) was used to classify grass species into groups based on DOM values. The daily mean temperature during the 2 trials was recorded from 1 month before the first cut until the last day of sampling in order to compare data of different years. Data analysis was carried out on SPSS.10 for Windows.

\section{RESULTS}

\section{Comparing Species Ranking Among Leaf Traits and Forage Nutritive Criteria}

For chemical-enzymatic analyses, the Spearman coefficient showed that SLA measured in summer 2001 was correlated significantly negatively with the fiber content and its components (Table 2) and significantly positively with the IV-DOM. LDMC and LLS measured in summer 2001 and spring 2002 were correlated positively with both fiber and hemi-cellulose contents and negatively with IV-DOM. LLS, measured only in spring 2002, was significantly positively correlated with the lignin.

For NIRS-analyses, a similar correlation trend between leaf traits and fiber content, hemi-cellulose and NIRS-DOM was found (Table 3). SLA measured during spring 2002 was not significantly correlated with the IV-DOM, whereas it was significantly correlated with the NIRS-DOM. A significant correlation was found between LDMC, SLA, LLS and lignin contents whatever the growing year (i.e. summer or spring) except between LLS and lignin in summer 2001.

The Spearman test was also used to compare species rankings by leaf trait values averaged over 2 growth periods with rankings from chemical-enzymatic and NIRS analyses (Tables 2 and 3). Leaf traits (LDMC, SLA and LLS) were 
Table 5. Species ranking for digestible organic matter (DOM in $\mathrm{g} \cdot \mathrm{kg}^{-1}$ ) and quality classes according to hierarchical ascending classification based on Euclidian distances. Values in this table are: mean \pm standard deviation.

\begin{tabular}{lllll}
\hline \multicolumn{1}{c}{ Species } & IV-DOM & NIRS-DOM & $\begin{array}{c}\text { Difference } \\
\text { between groups }\end{array}$ & $\begin{array}{c}\text { Quality } \\
\text { class }\end{array}$ \\
\hline Anthoxanthum odoratum & $824 \pm 8$ & $845 \pm 7$ & High \\
Holcus lanatus & $785 \pm 13$ & $842 \pm 1$ & & \\
Lolium perenne (cV Clerpin) & $792 \pm 2$ & $806 \pm 7$ & & \\
Arrhenatherum elatius & $834 \pm 4$ & $828 \pm 1$ & & \\
mean & $809 \pm 24$ & $830 \pm 18$ & 21 & Medium \\
Dactylis glomerata & $732 \pm 17$ & $788 \pm 7$ & & \\
Agrostis capillaris & $727 \pm 9$ & $780 \pm 1$ & & \\
Brachypodium sylvaticum & $709 \pm 3$ & $747 \pm 14$ & & \\
Brize media & $769 \pm 17$ & $773 \pm 12$ & & \\
mean & $734 \pm 25$ & $772 \pm 18$ & 38 & \\
Festuca rubra & $597 \pm 15$ & $735 \pm 9$ & & \\
Festuca ovina & $634 \pm 48$ & $739 \pm 17$ & & \\
Festuca arundinacea & $651 \pm 25$ & $731 \pm 6$ & & \\
Brachypodium pinnatum & $619 \pm 11$ & $701 \pm 7$ & & \\
Avenula pubescens & $671 \pm 21$ & $700 \pm 4$ & & \\
mean & $634 \pm 29$ & $721 \pm 19$ & 87 & \\
\hline
\end{tabular}

IV-DOM: in vitro method used on youngest adult blades harvested in 2001; NIRS-DOM: Near Infrared reflectance Spectroscopy (NIRS) analysis done on all the green blades of tillers harvest in 2002.

Consequently, we suggest a revision of these empirical specific indices by analyzing the tissues.

Our results for DOM values were in accord with those presented by Halliday (1989) who reported that the degradability in the rumen of $A$. capillaris was less than that of $H$. lanatus by 60 $\mathrm{g} \cdot \mathrm{kg}^{-1}$ for vegetative regrowth (leafy biomass). Furthermore, working on natural communities, Duru et al. (2004) showed that there is a difference in IV-DOM of $80 \mathrm{~g} \cdot \mathrm{kg}^{-1}$ between a typical species from nutrient-rich $(D$. glomerata) and one from nutrientpoor (F. rubra) habitats. Differences reported by these authors are close to the differences that we observed between the same species using the NIRS method (Table 5).

In our work, species ranking for their nutritive value based on plant analysis methods was found when the functional plant approach was used. Spearman rank coefficients calculated between leaf traits and nutritive value criteria (Tables 2 and 3) suggest that species having leaf traits characteristic of nutrientpoor habitats (i.e., low SLA, high LDMC and long LLS) have a high fiber content, confirming results reported previously for grasses (Poorter and Bergkotte 1992; Van Arendonk and Poorter 1994). Leaves with a long lifespan show a high fiber concentration (Eckstein et al. 1999) and a high ability to store nutrients (Escudero et al. 1992; Aerts and Chapin 2000). We have shown that leaf traits also rank species for their leaf digestibility. For example, B. pinnatum, F. ovina and F. rubra, belonging to the third group of DOM, are species characteristic of poor habitats (Poorter and Remkes 1990; Lambers and Poorter 1992; Niemann et al. 1992; Ryser 1996). Conversely, A. elatius and $H$. lanatus, species typical of very fertile habitats (Niemann et al. 1992; Elberse and Berendse 1993; Ryser 1996; Vazquez de Aldana and Berendse 1997), had the highest DOM values. Wilson (1993) reported that the lower digestibility of species preferring low nutrient habitats is the consequence of their chemical composition and also of their tissue anatomy, because they tend to have a high proportion of non-veinal sclerenchymatic cells (Van Arendonk and Poorter 1994).

The correlations between leaf DOM and leaf traits, especially LDMC, were weak $(r=0.48$ and 0.62 according to the analyses methods), but highly significant $(P \leq 0.001)$. We do not consider this result as poor. Indeed, as explained in the introduction, plant traits were originally proposed as a way of classifying species according to their growth characteristics. Their use for the evaluation of nutritive value is an additional application and can be relatively rough. Moreover, the method is intended to be applied at the plant community level, weighting plant traits by the abundance of each species. Consequently, the risk of error should be smaller than if the method is applied to pure stands.

\section{Criticisms of Plant Sampling and Analysis Methods}

The higher mean value of the leaf blade fiber content and the lower mean value of leaf blade DOM in 2001 compared with those in 2002 can be explained by the differences: 1) in the analyzed plant organ between species; and/or 2) in the method used for plant analysis; and/or 3) the specific environmental conditions in the year of sampling. In spite of these differences, ranking species by digestibility and fiber content was independent of years, organs and analysis methods. These 3 hypotheses are discussed below.

A difficulty with comparing the nutritive value of species having contrasting resource use strategies is to rigorously decide at what time to harvest the plant material. In our work, leaf sampling time was based on plant phenology. For chemical-enzymatic analyses, it was the time at which a lamina reaches its final length. For NIRS-analyses, it was the beginning of stem elongation, which is easy to observe. Whereas the youngest fully-expanded blades (chemical-enzymatic analyses) were harvested at a similar time, they had different ages, like laminae harvested for NIRS-analyses (see material and method). Indeed, for chemical-enzymatic analyses, the species having longer LLS also had a longer time between a lamina's appearance and its full expansion (Al Haj Khaled, unpublished data). Furthermore, previous results on D. glomerata (Duru and Ducrocq 2002) have shown that the digestibility of the youngest fully-expanded lamina and those of the pooled green lamina were significantly correlated, regardless of growing season or nitrogen treatment. Consequently, we do not think that the sampling method was the reason for the differences in DOM values between growing seasons.

As far as the method for estimating digestibility is concerned, an earlier study comparing blades or stems of grasses from rich and poor habitats did not show any differences between the enzymatic and NIRS methods (Duru et al. 2004).

We wondered whether the differences in leaf blade fiber content and leaf DOM values between the two analyses methods were due to weather conditions during the growing periods. Calculated daily mean temperatures were $20.2 \pm 2.6^{\circ} \mathrm{C}$ and 11.9 $\pm 2.7^{\circ} \mathrm{C}$ for chemical-enzymatic and NIRS analyses, respectively. In fact, temperature usually has a greater influence on forage quality than other environmental factors encountered by plants (Buxton and Fales 1994). According to these authors, temper- 
ature influences the rate of plant development, the relative proportion of leaf and stem weights and the tissue type within leaves or stems. Plants invest more carbon into structural components at high temperatures (Deinum and Dirven 1975), increasing the lignin (Dirven and Deinum 1977; Pitman and Holt 1982; Wilson et al. 1991), and the neutral detergent fiber content (Henderson and Robinson 1982). An increase in temperature of $1^{\circ} \mathrm{C}$ decreased the leaf blade digestibility by 6 $\mathrm{g} \cdot \mathrm{kg}^{-1}$ for Dactylis glomerata, and by $5.3 \mathrm{~g} \cdot \mathrm{kg}^{-1}$ for Festuca arundinacea (Duru et al. 1995). On this basis, the expected difference in leaf blade DOM due to the difference in temperatures between the 2 years is around $45 \mathrm{~g} \cdot \mathrm{kg}^{-1}$, which is close to those observed in our work (Table 5).

Although higher leaf fiber and lower digestibility in 2001 appear to be due to greater average temperature, we could not completely exclude an effect due to sampling procedure and to the method used for plant analysis. However, whatever the factors causing the variability in species nutritive value between the 2 analyses methods, the species ranking was conserved (Table 4), as was also observed for leaf traits (Al Haj Khaled et al. 2005).

\section{MANAGEMENT IMPLICATIONS}

Our work shows that leaf traits roughly rank grass species for their nutritive value as they do for their phenological stages (Ansquer et al. 2004) and growth rate (Grime and Hunt, 1975). Regarding the applied objective of this work, that is, to identify leaf traits useful to diagnose the state of the vegetation especially their nutritive value and to identify species groups having similar management needs, traits should be easy to measure, as anything difficult or time-consuming will be impractical for many species (Wilson et al. 1999).

SLA presents two difficulties. Firstly, it showed a practical difficulty with plants having vertically-oriented leaves, or worse still, no leaves. Secondly, it can vary as result of changes in leaf thickness, composition, or both (Wilson et al. 1999). Contrarily, LDMC is relatively easy to measure, largely independent of leaf thickness and much less variable than SLA and LLS (Al Haj Khaled et al. 2005). Consequently, we propose to use LDMC as a tool to rank species according to their nutritive value.

However, further research is needed to see if LDMC is a suitable tool to rank natural grasslands for their nutritive value for a set of fields, or within a farm. We suggest the use of LDMC to rank grassland communities for their herbage DOM in two ways (Duru et al. 2005). First, ranking could be done by measuring LDMC for the dominant species weighted by their abundance. Second, we propose to use a LDMC database (Al Haj Khaled et al. 2005) when species recordings are already available. The latter method was applied in two previous studies Duru (1994) and Duru (1997). In each of these studies, it was shown that grass leaf digestibility recorded on 2 sets of natural grasslands was high for those dominated by $D$. glomerata, $H$. lanatus, and L. perenne (species having low LDMC), and low for those dominated by Festuca rubra and $A$ capillaris (species having high LDMC).

Finally, when LDMC is measured at the plant community level, it may be possible to simplify these measurements, sampling leaves at random and not identifying species.

\section{LITERATURE CITED}

Aerts, R., And F. S. III. Chapin. 2000. The mineral nutrition of wild plants revisited: a re-evaluation of processes and patterns. Advances in Ecological Research 30:1-67.

Al Hau Khaled, R., M. Duru, J. P. Theau, S. Plantureux, and P. Cruz. 2005. Variations of leaf traits through seasons and $\mathrm{N}$ availability levels and consequences for ranking grassland species according to their habitat preference. Journal of Vegetation Science 16:391-398.

Ansquer, P., J. P. Theau, P. Cruz, J. Viegas, R. Al Haj Khaled, and M. Duru, 2004. Caractérisation de la diversité fonctionnelle des prairies naturelles. Une étape vers la construction d'outils pour gérer les milieux à flore complexe. Fourrages 179:353-368.

Aufrère, J. 1982. Etude de la prévision de la digestibilité des fourrages par une méthode enzymatique. Annales Zootechnie 31:111-130.

Balent, G., and M. Duru. 1984. Influence des modes d'exploitation sur les caractéristiques et évolution des surfaces pastorales: cas des Pyrénées centrales. Agronomie 4:113-124.

Biston, R., and P. Dardenne. 1985. Application de la spectrométrie de réflexion dans le proche infra-rouge. Prévision de la qualité des fourrages en vue de leur exploitation rationnelle. Bulletin des Recherches Agronomiques de Gembloux 20:23-41.

Bruinenberg, M. H., H. Valk, H. Korevaar, and P. C. Struik. 2002. Factors affecting digestibility of temperate forages from semi-natural grasslands: a review. Grass and Forage Science 57:292-301.

Buxton, D. R., And S. L. Fales. 1994. Plant environment and quality. In: Fahey, G.C., M. Collins, D. R. Mertens, and L. E. Moser [EDS.]. Forage quality, evaluation and utilisation. Madison, WI. p 155-199.

DACCORD, R. 1991. Valeur nutritive des foins de prairies riches en espèces. Revue Suisse d'Agriculture 23:36-40.

Daget, P., And J. Poissonnet. 1971. Une méthode d'analyse phytosociologique des prairies. Annales Agronomiques 22:5-41.

Dardenne, P., AND R. BISton. 1991. Standardization procedure and NIR instrument network. In: R. Biston, and T. Bartiaux [ED.]. Proceedings 3rd International Conference on NIS, Agricultural Research Center Publisher Belgium, p 655.

Dardenne, P., G. Sinnaeve, L. Bollen, and R. Agneessens. 1996. NIT-NIR calibration list, Libramont, Station de Haute Belgique.

De VRIES, D. M. 1937. Methods of determining the botanical composition of hay fields and pastures. Rep IVth International Grassland Congress Aberystwyth. p 474-480.

Deinum, B., And J. G. Dirven. 1975. The effect of temperature on the digestibility of grasses. An Analysis. Forage Research 3:1-17.

DELPECH, R. 1960. Critères de jugement de la valeur agronomique des prairies. Fourrages 4:83-98.

Demarouilly, C. 1989. The feeding value of forages. In: Proceedings of XVI International Grassland Congress; 4-11 October 1989; Nice, France. p 1817-1823.

Demarquilly, C., and R. Jarrige. 1981. Panorama des méthodes de prévision de la digestibilité et de la valeur énergétique des fourrages. In: C. Demarquilly [ED.]. Prévision de la valeur nutritive des aliments de ruminants. Versailles, France: INRA Editions. p 13-40.

Diaz, S., N. Pérez-Harguindeguy, F. Vendrami, and S. Basconcelo. 1999. Plant traits as links between ecosystem structure and functioning. In: D. Eldridge, and D. Freudenberger [EDS.]. Proceedings of the VI International Rangeland Congress; 19-23 July, Townsville, Queensland, Australia. p 896-901.

Dirven, J. G. P., AND B. Deinum. 1977. The effect of temperature on the digestibility of grasses: an analysis. Forage Research 3:1-17.

Dorioz, J. M., AND J. P. PARTY. 1987. Dynamic ecology and typology of pasture lands in the northern Alps. 1. Analysis of agro-ecological organization of a reference alpine grazing area. Acta Oecologica Oecologia Applicata 8:283-300.

Duru, M. 1994. Mineral nutrition status botanical composition of pastures. IIEffect on herbage nitrogen content and digestibility. European Journal of Agronomy 3:125-133.

DuRu, M. 1997. Leaf and stem in vitro digestibility for grasses and dicotyledons of meadow plant communities in spring. Journal of the Science of Food and Agriculture 74:175-185. 
DuRu, M., AND H. Ducroca. 2002. A model of lamina digestibility of orchard grass as influenced by nitrogen and defoliation. Crop Science 42:214-223.

Duru, M., I. Calvière, and V. TiRilly. 1995. Evolution de la digestibilité in vitro du dactyle et de la fétuque élevée au printemps. Fourrages 141:63-74.

Duru, M., P. CRuz, And D. Magda. 2004. Using plant traits to compare sward structure and composition of grass species across environmental gradients. Applied Vegetation Science 7:11-18.

Duru, M., J. Tallowin, and P. Cruz. 2005. Functional diversity in low input grassland farming systems: characterization, effect and management. Agronomy Research 3:125-138.

Eckstein, R. L., P. S. Karlsson, and M. Weih. 1999. Leaf life span and nutrient resorption as determinants of plant nutrient conservation in temperate-arctic regions. New Phytologist 143:177-189.

Elberse, W. Th., and F. Berendse. 1993. A comparative study of the growth and morphology of eight grass species from habitats with different nutrient availabilities. Functional Ecology 7:223-229.

Escudero, A., J. M. del Arco, I. C. Sanz, and J. Ayala. 1992. Effects of leaf longevity and retranslocation efficiency on the retention time of nutrients in the leaf biomass of different woody species. Oecologia 90:80-87.

EverITT, B. 2001. Cluster Analysis. Oxford University Press US. ISBN 0340761199. $248 \mathrm{p}$.

Fick, G. W., P. W. Wilkens, and J. H. Cherney. 1994. Modeling forage quality changes in the growing crop. In: G. C. Fahey, M. Collins, D. R. Mertens, and L. E. Moser [EDS.]. Forage quality, evaluation and utilization. Madison, WI: American Society of Agronomy. p 757-795.

Garnier, E., and G. LauRent. 1994. Leaf anatomy, specific mass, and water content in congeneric annual and perennial grass species. New Phytologist 28:725-736.

Grime, J. P., And R. Hunt. 1975. Relative growth rate: its range and adaptive significance in a local flora. Journal of Ecology 63:393-422.

Groot, J. C. J., And J. H. Neuteboom. 1997. Composition and digestibility during ageing of Italian ryegrass leaves of consecutive insertion levels. Journal of the Science of Food and Agriculture 75:227-236.

HallidAY, L. J. 1989. Rumen degradation of various grass species at different stages of growth. In: Proceedings of XVI International Grassland Congress; 4-11 October 1989; Nice, France. p 933-934.

Henderson, M. S., and D. L. Robinson. 1982. Environmental influences on yield and in vitro true digestibility of warm-season perennial grasses and the relationships to fiber components. Agronomy Journal 74:943-946.

Hopkins, C., J. P. Marais, and D. C. W. Goodenough. 2002. A comparison, under controlled environmental conditions, of a Lolium multiflorum selection bred for high dry-matter content and non-structural carbohydrate concentration with a commercial cultivar. Grass Forage Science 57:367-372.

KLAPP, E. 1965. Taschenbuch der Gräser. Berlin: Paul Parey. 260 p.

Lambers, H., and H. POORTER. 1992. Inherent variation in growth rate between higher plants: a search for physiological causes and ecological consequences. Advances in Ecological Research 23:187-261.

Lavorel, S., and E. Garnier. 2002. Predicting changes in community composition and ecosystem functioning from plant traits: revisiting the Holy Grail. Functional Ecology 16:545-556.

Marten, H., And S. A. Jensen. 1982. Partial least squares regression: a new two stages NIR calibration method. In: Holas and Katchovil [ED.]. Proceedings $7^{\text {th }}$ World Cereal Bread Congress. Elsevier. p 607-647.
Meziane, D., and B. Shipley. 1999. Interacting determinants of specific leaf area in 22 herbaceous species: effects of irradiance and nutrient availability. Plant and Cell Environment 22:447-459.

Nelson, C. J., And L. E. Moser. 1994. Plant factors affecting forage quality. In: G. C. Fahey, M. Collins, D. R. Mertens, and L. E. Moser [EDS.]. Forage quality, evaluation, and utilization. Madison, WI: American Society of Agronomy. $p$ $115-154$.

Niemann, G. J., J. B. M. Purveen, G. B. Elukel, H. Poorter, and J. J. Boon. 1992. Differences in relative growth rate in 11 grasses correlate with differences in chemical composition as determined by pyrolysis mass spectrometry. Oecologia 89:567-573.

Olsen, S. R., C. V. Cole, F. S. Watanabe, and L. A. Dean. 1954. Estimation of available phosphorus in soils by extraction with sodium bicarbonate. USDA, Circ 939, Washington, DC: US Government Print Office, $19 \mathrm{p}$.

Pitman, W. D., and E. C. Holt. 1982. Environmental relationships with forage quality of warm-season perennial grasses. Crop Science 22:1012-1016.

PoORTeR, H., AND C. Remkes. 1990. Leaf area ratio and net assimilation rate of 24 wild species differing in relative growth rate. Oecologia 83:553-559.

Poorter, H., AND M. Bergkotte. 1992. Chemical composition of 24 wild species differing in relative growth rate. Plant and Cell Environment 15:221-229.

Poorter, H., C. Remkes, and H. Lambers. 1990. Carbon and nitrogen economy of 24 wild species differing in relative growth rate. Plant Physiology 94:621-627.

Reich, P. B., M. B. Walters, and D. S. Ellsworth. 1992. Leaf life-span in relation to leaf, plant and stand characteristics among diverse ecosystems. Ecological Monographs 62:365-392.

RYSER, P. 1996. The importance of tissue density for growth and life-span of leaves and roots: a comparison of five ecologically contrasting grasses. Functional Ecology 10:717-723.

SHESKIN, D. J. 2004. Handbook of parametric and nonparametric statistical procedures. $3^{\text {rd }}$ ed. Boca Raton, FL: Chapman \& Hall/CRC. 1193 p.

Tilley, J. M. A., and R. A. A. TerRy. 1963. Two stage technique for the in vitro digestion of forage crops. Journal of the British Grassland Society 18: 104-111.

Van Arendonk, J. J. C. M., and H. Poorter. 1994. The chemical composition and anatomical structure of leaves of grass species differing in relative growth rate. Plant and Cell Environment 17:963-970.

Van Der Honing, Y., and G. Alderman. 1988. III. Feed evaluation and nutritional requirements 2. Ruminants. Livestock Production Science 19:217-278.

Van Soest, P. J., and R. H. Wine. 1967. Use of Detergents in the Analysis of Fibrous Feeds. IV. Determination of plant Cell-Wall constituents. Journal AOAC 50: 50-55.

Vazquez de Aldana, B. R., and F. Berendse. 1997. Nitrogen use efficiency in six perennial grasses from contrasting habitats. Functional Ecology 11:619-626.

Wilson, J. R. 1993. Organization of forage plant tissues. In: H. J. Jung, D. R. Buxton, R. D. Hatfield, and J. Ralph [EDS.]. Forage Cell Wall Structure and Digestibility. Madison, WI: ASA, CSSA, SSSA. p 1-32.

Wilson, J. R., B. Deinum, And F. M. Engels. 1991. Temperature effects on anatomy and digestibility of leaf and stem of tropical and temperate forage species. Netherlands Journal of Agricultural Science 39:31-48.

WiLson, P. J., K. Thompson, And J. G. Hodgson. 1999. Specific leaf area and leaf dry matter content as alternative predictors of plant strategies. New Phytologist 143:155-162 